Journal of Southeast Asian

\title{
Educational Careers of Hmong American Students
}

Pao Lor

University of Wisconsin-Green Bay, lorp@uwgb.edu

Ray Hutchison

University of Wisconsin-Green Bay, hutchr@uwgb.edu

Follow this and additional works at: https://docs.lib.purdue.edu/jsaaea

Part of the Bilingual, Multilingual, and Multicultural Education Commons, Disability and Equity in Education Commons, and the Higher Education Commons

\section{Recommended Citation}

Lor, Pao and Hutchison, Ray (2017) "Educational Careers of Hmong American Students," Journal of Southeast Asian American Education and Advancement. Vol. 12 : Iss. 1, Article 3.

DOI: $10.7771 / 2153-8999.1148$

Available at: https://docs.lib.purdue.edu/jsaaea/vol12/iss1/3

This document has been made available through Purdue e-Pubs, a service of the Purdue University Libraries. Please contact epubs@purdue.edu for additional information.

This is an Open Access journal. This means that it uses a funding model that does not charge readers or their institutions for access. Readers may freely read, download, copy, distribute, print, search, or link to the full texts of articles. This journal is covered under the CC BY-NC-ND license. 


\section{Educational Careers of Hmong American Students}

\section{Cover Page Footnote}

We like to thank Dean Sue Mattison, College of Health, Education and Social Welfare, for the financial support of this study. 


\title{
USAAEA Journal of Southeast Asian American Education and Advancement
}

Vol. 12 Iss. 1 (2017)

WWW.ISAAEA.org

\section{Educational Careers of Hmong American Students}

\author{
Pao Lor \\ University of Wisconsin-Green Bay \\ Ray Hutchison \\ University of Wisconsin-Green Bay
}

\begin{abstract}
Hmong American college students are an underrepresented and understudied college student population. The Hmong are often described as a preliterate, semi-nomadic, and agrarian ethnic hill tribe from Southeast Asia that have had little contact with formal education before coming to the United States some four decades ago. In this descriptive and exploratory study, we analyze the demographic characteristics and educational achievement of one hundred ninetyfour $(n=194)$ Hmong students who were admitted to and attended a four-year state university in the Midwest from 2002-2010. We summarize their demographic data and academic achievement, and we compare their academic achievement to that of their college peers. We also examine correlations between their high school academic achievement and their college academic progress, and we report on their post-secondary outcomes.
\end{abstract}

Keywords: Hmong American students, Hmong American educational achievement, underrepresented college students, understudied college students, first generation college students

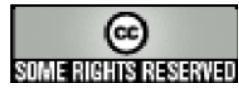

Readers are free to copy, display, and distribute this article, as long as the work is attributed to the author(s) and the Journal of Southeast Asian American Education \& Advancement, it is distributed for non- commercial purposes only, and no alteration or transformation is made in the work. More details of this Creative Commons license are available at http://creativecommons.org/licenses/by-nc-nd/3.0/. All other uses must be approved by the author(s) or JSAAEA. Journal of Southeast Asian American Education \& Advancement, Vol. 12. Iss. 1. (2017) ISSN: 2153-8999 


\section{Introduction}

The Hmong are originally a preliterate, semi-nomadic, and agrarian ethnic hill tribe from Southeast Asia and have been in the United States for just four decades. From the 1960s to the mid-1970s, the Hmong joined forces with the United States during The Secret War in Laos. After the United States pulled out of Laos in 1975, the new Laotian regime began persecuting the Hmong for having supported the United States. From 1975 to 2014, the United States relocated several waves of Hmong refugees to the United States. The accounts by Hendricks, Downing, and Deinard (1986), Yang (1993), Long (1993), Koltyk, (1997), Hamilton-Merritt (1999), and Hillmer (2010), along with anecdotal stories streaming through the Hmong community, capture the essence of such Diaspora. The essence of Diaspora includes life in Laos, life in Thailand, and life in the United States - a life history that entails the transition and transformation of an ancient and agrarian way of life. According to the 2010 US Census, there are 260,073 Hmong residing in the 50 states, District of Colombia, and Puerto Rico (Hoeffel, Rastogi, Kim, \& Shahid, 2012).

The Hmong first encountered formal education in Laos in the 1930s and early 1940s during French colonialism of Indochina. The first Hmong scholar to conduct a formal study on the Hmong American educational experience was Dao Yang in the 1960s. At the time, he was a doctoral student in France. His research, titled "Hmong at the Turning Point", would eventually be published in the United States in 1993. In a segment of this research, Yang highlights some of the earliest Hmong formal educational experiences in Laos including Hmong students' transitioning from their tribal villages to formal school classrooms during French colonialism, some of the first Hmong students to study abroad, and some of the first Hmong classroom teachers.

Formal education continued to play a critical role for the Hmong after relocating to Thailand as war and political refugees from the 1970s to the 2000s. Lor (2009) and Long (1993) touch on some of their formal educational experiences in Thailand. Both provide insights into how Thai educational policies and practices affected Hmong refugee students' educational experiences. Lor specifically looks at their educational experience at Wat Thamkrabok from the 1990s to 2000s while Long looks at their educational experience as refugees living in Ban Vinai in the 1980s. In both cases, though limited in educational resources such as a lack of qualified teachers and a lack of learning materials, education still plays a critical role in advancing the Hmong's capacity to communicate with the outside world and in giving them hope about their place in society.

Since the Hmong first arrived on American soil in 1975, teachers, administrators, parents, leaders, and community organizations, given the Hmong students' preliterate and cultural background, have been actively involved in making the Hmong students' educational experience a positive and engaging one, driven by the belief that education should and must play a critical role in guiding Hmong students to become productive individuals. Another stakeholderresearchers have also been exploring, examining, and reporting on many aspects of the Hmong student's experience in the preK-12 educational system and more recently, the Hmong student's experience in post-secondary education.

The following research highlights the Hmong students' educational experience over the last four decades: In 1985, Goldstein examines the cultural challenges that Hmong males and females endure as they transitioned to American high schools. Hutchison (1997) used several categories of academic data and interviews, reports on Hmong students' academic performance in the preK-12 educational system in Wisconsin, asserting that for most Hmong students' academic performance were on par with that of their peers. Vang (2001, 2003, 2004, 2005) provides 
critical insights into the cultural and academic experiences of Hmong students in the California's preK-11 educational system, reporting that cultural factors continue to affect Hmong students' achievement. As for the Hmong students' experience in post-secondary education, Ngo (2000) and Lor (2008) explored several factors (educational, social, cultural, and institutional) contributing to Hmong college students' matriculation, retention, and graduation. DePouw (2003, 2006, 2012) used a critical race lens to examine how higher education institutional policies, practices, and culture affect Hmong college students' academic and cultural experiences. Lee (1997) and Lor (2013) provide insights into the cultural and academic challenges female Hmong college students have to wrestle with and balance as they make their way through college.

The current landscape of the Hmong formal educational experience, particularly in regard to Hmong educational attainment in the United States, is captured by two reports generated by Hmong National Development (2003, 2013). Using educational data from the 2000 and 2010 censuses, Hmong National Development (HND) points out that in 2000, $45.3 \%$ of the Hmong population have no formal education as compared to $1.4 \%$ of the total U.S. population, $27 \%$ of the Hmong population have a high school diploma, $11.7 \%$ have associate's or bachelor's degrees, and $1.5 \%$ have graduate degrees. In 2010, $14.5 \%$ of the Hmong population above the age of 25 have attained a bachelor's degree or higher lagging behind $31.4 \%$ of non-Hispanic whites, $18 \%$ of nonHispanic blacks, and 50.2\% of non-Hispanic Asians. Pfeiffer, Chiu, and Yang (2013) also provide a critical window to what Hmong college graduates have done with their educational achievement and reporting that the progress looks promising with education paving the way for many Hmong professionals to move into politics, education, business, and leadership positions. Also on a more promising note, Xiong (2012) reports the number of Hmong who are between the ages of 18 and 21 and are attending college in the five most populated states to be increasing: California (76.3\%), Minnesota (54.9\%), Wisconsin (73.1\%), North Carolina (73.8), and Michigan (49.5\%). As for the rest of the states, the figure is $83.6 \%$.

While existing research captures the educational, cultural, and social dynamics influencing the Hmong students' educational experience, and whereas there are raw data capturing the Hmong students' educational performance in the preK-12 educational system, there is a lack of raw data and information to capture the Hmong student's college educational achievement. It is this lack of raw data on the Hmong college students' educational achievement that propelled our study. More specifically, we wanted to find out about their high school educational achievement, their college educational achievement, the correlations between their college educational achievement and their high school academic achievement, the comparison between their educational achievement and that of their peers, and their post-secondary outcomes.

We chose to focus our study on Hmong students who were admitted to and attended the University of Wisconsin-Green Bay from 2002-2010. UW-Green Bay is one of the thirteen four year campuses in the UW-System, located in a medium sized metropolitan area with a population of some 300,000 persons. Wisconsin has the third largest Hmong population in the United States with over 49,000. Wisconsin cities with high Hmong populations include Milwaukee, Green Bay, Appleton, Sheboygan, La Crosse, Wausau, and Eau Claire.

We chose UW-Green Bay (UWGB) for our study for several reasons. One, UW-Green Bay was the institution where our sampling and the data we wanted to analyze were accessible and available. Two, UW-Green Bay is a four-year comprehensive institution like the other ten University of Wisconsin institutions (UW-Stevens Point, UW-Stout, UW-River Falls, UW-Eau Claire, UW-Whitewater, UW-Plateville, UW-LaCrosse, UW-Oshkosh, UW-Parkside, and UWSuperior). Undergraduate and graduate student enrollment at these institutions from 2002-2010 
ranges from about 2,300 at UW-Superior to over 10,000 at UW-Oshkosh, UW-Eau Claire, and UW-Whitewater. UW-Green Bay falls in the middle with about 5,000 students. Three, the historical estimates of Hmong students enrollment (classified under Southeast Asian American by UW-System) at UW-Green Bay is similar to that of the other seven comprehensive UW institutions (UW-Eau Claire, UW-LaCrosse, UW-Oshkosh, UW-River Falls, UW-Stevens Points, UWStout, and UW-Whitewater). The historical estimates of Hmong student enrollment at these seven campuses and UW-Green Bay from 2002-2010 range from the 70s to over 300. The total estimate of number of Hmong student enrollment in the UW-System from 2002-2010 is about 20,000, with the largest enrollment in 2010 with over 3,000. Four, giving these similarities among these eight comprehensive UW institutions, we figured our findings from our UW-Green Bay study could be relevant to them. Additionally, we can also duplicate the study at these other comprehensive UW institutions to add more depth to our UW-Green Bay findings. The same could be said of other similar comprehensive universities that are outside of the UW-System.

We excluded statistics on Hmong student enrollment at UW's two year community colleges because their admission criteria and the learning and teaching dynamics of their institutions are different than the ten (10) aforementioned comprehensive UW institutions. We also excluded statistics on Hmong student enrollment at UW-Milwaukee and UW-Madison, giving that they are University of Wisconsin's doctoral institutions.

\section{Methods}

Our study is descriptive and exploratory. It is descriptive in that we describe a range of data concerning the post-secondary academic progress of the students in our study, and it is exploratory in that we hope our analysis will prove to be a good start for furthering studies on the Hmong college student experience and that our analysis could lead to new discoveries about and connections among the variables that could affect the Hmong college student experience.

Our study was guided by the following five sets of questions:

- What are the demographic characteristics of UW-Green Bay Hmong students? Where did they come from (city and state)? What high school did they graduate from? What is the clan representation of the Hmong students? What is the gender make up? How is the students' gender related to educational outcomes?

- What is their high school educational achievement? What are their ACT scores? What is their high school GPA? How many credits did you earn in math, English, science, social studies, and foreign language?

- What about their post-secondary educational progress? How many credits do they earn per semester? What is their grade point average per semester and for the time they are at the university? How many semesters are they enrolled in post-secondary? What are their educational outcomes -- How many graduated? How many transferred? How many dropped out? What if they transferred or dropped out? What happened to them? Did enroll at another university? Did they graduate after transferring to another university?

- How does Hmong students' academic achievement compare to that of the majority students' academic achievement?

- Are there correlations between their college educational performance and their high school 
achievement?

\section{Sampling}

In our first step to get our sampling, we asked the Office of Institutional Research and Assessment at UW-Green Bay for a list of students who were admitted to and enrolled at UW-Green Bay from 2002-2010. Of special interest are those students who had identified their Institutional Race/ Diversity code as one of the following nine (9) categories where we know that Hmong students may be classified: HMONG, ASIAN, HMONG, ACAMLAOV, HMONG, HMONG, LAOTIAN, OTHRASN, ACAMLAOV, ASIAN, OTHERASN, ACAMLAOV, ASIAN, AND NSPEC, as well as those students who had identified their UW- System Ethnicity code as Southeast Asian. We used these categories to ensure we did not miss any Hmong students who might not have identified their University of System Ethnicity Code as Southeast Asian and vice versa. We used the National Center for Educational Statistics' six-year graduation rate for college students to complete a bachelor's degree to select our 2002-2010 Hmong student cohorts (2016).

Our initial list included more than two hundred students. To ensure our sampling includes only Hmong students, we first looked at their Institutional Racial/Diversity Code(s). We included all students who had identified themselves as "HMONG" in their Institutional Racial/Diversity Code(s): HMONG ( $\mathrm{n}=61)$, ASIAN, HMONG $(\mathrm{n}=24)$, ACAMLAO, HMONG $(\mathrm{n}=12)$, and HMONG, LAOTIAN, OTHRASN ( $\mathrm{n}=1$ ). Next, for students who had identified their Institutional Race/Diversity Code(s) as ACAMLAOV, ASIAN, OTHERASN, ACAMLAOV, ASIAN, AND NSPEC, giving that different Southeast Asian groupss have distinctive last names, we examined their last names or variations of their last names to see if they match one of these eighteen (18) Hmong clan names: Chang/Cha, Chue/Chu, Cheng, Fang, Her/Heu, Hang, Khang, Kong, Kue, Lee/Ly, Lao/Lo/Lor, Moua/Mua, Pha, Thao/Thor, Vang/Wang/Va, Vu/Vue, Xiong, and Yang. Our final sampling ended up being one hundred ninety-four Hmong students $(n=194)$ who were admitted to and attended UW-Green Bay from 2002-2010.

\section{Data}

In 2015, we requested information from the Office of Institutional Research and Assessment at UW-Green Bay about our sample. We aggregated the data into these categories: demographics, high school educational achievement, college educational achievement, and post-secondary educational outcomes. Demographics included cohorts, gender, clan represented, high school represented, cities and states they were coming from, and other notable academic highlights. High school educational achievement included their high school credit units in English, math, science, and social studies, ACT Scores including composite scores and ACT scores in English, math, reading, and science, and high school GPA. College educational achievement included their total credits earned, GPA, withdrawal from the university, degree completion, and related measures such as years to degree completion. Post-secondary educational outcomes included the number of graduates, number of graduates by gender, number of students who transferred to another post-secondary institution, students who dropped out, and number of transferred students who graduated from other educational institutions, including two year schools $(\mathrm{n}=12)$ and four year colleges and universities $(\mathrm{n}=14)$.

Diversity code as one of the following nine (9) categories where we know that Hmong 
students may be classified: HMONG, ASIAN, HMONG, ACAMLAOV, HMONG, HMONG, LAOTIAN, OTHRASN, ACAMLAOV, ASIAN, OTHERASN, ACAMLAOV, ASIAN, AND NSPEC, as well as those students who had identified their UW- System Ethnicity code as Southeast Asian. We used these categories to ensure we did not miss any Hmong students who might not have identified their University of System Ethnicity Code as Southeast Asian and vice versa. We used the National Center for Educational Statistics' six-year graduation rate for college students to complete a bachelor's degree to select our 2002-2010 Hmong student cohorts (2016).

Our initial list included more than two hundred students. To ensure our sampling includes only Hmong students, we first looked at their Institutional Racial/Diversity Code(s). We included all students who had identified themselves as "HMONG" in their Institutional Racial/Diversity Code(s): HMONG ( $n=61)$, ASIAN, HMONG $(n=24)$, ACAMLAO, HMONG $(n=12)$, and HMONG, LAOTIAN, OTHRASN ( $\mathrm{n}=1)$. Next, for students who had identified their Institutional Race/Diversity Code(s) as ACAMLAOV, ASIAN, OTHERASN, ACAMLAOV, ASIAN, AND NSPEC, giving that different Southeast Asian groupss have distinctive last names, we examined their last names or variations of their last names to see if they match one of these eighteen (18) Hmong clan names: Chang/Cha, Chue/Chu, Cheng, Fang, Her/Heu, Hang, Khang, Kong, Kue, Lee/Ly, Lao/Lo/Lor, Moua/Mua, Pha, Thao/Thor, Vang/Wang/Va, Vu/Vue, Xiong, and Yang. Our final sampling ended up being one hundred ninety-four Hmong students $(n=194)$ who were admitted to and attended UW-Green Bay from 2002-2010.

\section{Analysis of Data}

The high school educational achievement data and the college educational achievement data allowed us to build an academic profile of Hmong students who have attended UW-Green Bay and to compare their educational performance to that of all UW-Green Bay students.

The high school educational achievement data (variables) included their ACT composite and ACT subscores, high school GPA, and the number of high school credits in English, math, science, and social studies. These measures served as the independent variables for our analyses of college performance. The college educational achievement data (variables) included semesterby-semester measures such as credit hours earned, GPA, withdrawal from the university, degree completion, and related measures. These measures served as the dependent variables for our analyses of college performance.

Our analysis of the aforementioned data followed the usual model of status attainment developed at UW-Madison (the Wisconsin Model of Status Attainment) as far as the information from our data set will allow. In the early models of status attainment, most analyses made use of multiple regression models and disaggregated path models to determine the direct and indirect effects of independent and intervening variables. In many cases variables that did not meet the requirements for least-squares analyses (such as the dichotomous dependent variables withdrawal from university and degree completion) were presented as dummy variables. Later refinements led to the introduction of log-linear modules that allow for the more accurate analyses using variables often encountered in educational research that may not meet the requirements for leastsquares analysis. We used both linear regression and log-linear regression models to study the factors that account for the success of Hmong students and to compare the performance of Hmong students with their non-Hmong peers.

The variables used in our analysis are shown in Table 1. 
Table 1. Independent and dependent variables

\begin{tabular}{ll}
\hline \multicolumn{1}{c}{ Independent Variables } & \multicolumn{1}{c}{ Dependent Variables } \\
\hline Sex & College Credit hours earned \\
High School GP & College Grand point average \\
High School credits (English, math, science, social & Withdrawal from university \\
studies) & Degree completion \\
ACT Composite score & Years to degree completion \\
ACT subscores & \\
\hline
\end{tabular}

\section{Limitations}

Our study has limitations. We focused on one regional university. Data from other post-secondary institutions (two-year community colleges, technical colleges, research universities, and universities with higher Hmong student enrollment) will yield different results. Our analysis is further limited by what information is collected by the UW-System.

\section{Results}

We broke down the results of our analysis into four categories: Hmong Student Demographics, Hmong Students' High School Educational Achievement, Hmong Students' College Educational Achievement, and Hmong Students' Post-Secondary Educational Outcomes.

\section{Hmong Student Demographics}

The demographics we analyzed about Hmong students who were admitted, enrolled, and attended UW-Green Bay from 2002-2010 include freshman headcount of Hmong students, by gender, by clan, high school represented, and other notable academic highlights.

Table 2. Cohort year and freshman headcount

\begin{tabular}{crrr}
\hline Cohort Year & $\begin{array}{c}\text { Number of UWGB } \\
\text { Hmong Freshman } \\
\text { Headcount }\end{array}$ & $\begin{array}{c}\text { Total UWGB Freshman } \\
\text { Student Headcount }\end{array}$ & $\begin{array}{c}\text { Total UW-System } \\
\text { Freshman Headcount }\end{array}$ \\
\hline 2002 & 24 & 917 & 27,466 \\
2003 & 19 & 971 & 28,287 \\
2004 & 20 & 998 & 28,412 \\
2005 & 13 & 925 & 29,635 \\
2006 & 27 & 1,028 & 29,342 \\
2007 & 21 & 1,003 & 30,652 \\
2008 & 18 & 1,017 & 30,329 \\
2009 & 35 & 1,049 & 30,338 \\
2010 & 17 & 906 & 30,257 \\
TOTAL & 194 & 8,814 & 264,718 \\
\hline
\end{tabular}


Table 3. Student headcount by gender

\begin{tabular}{crrr}
\hline Cohort Year & $\begin{array}{c}\text { Number of UWGB Hmong } \\
\text { Freshman Headcount } \\
\text { (Female; Male) }\end{array}$ & $\begin{array}{c}\text { Total UWGB Freshman } \\
\text { Student Headcount } \\
\text { Male) }\end{array}$ & $\begin{array}{c}\text { Total UW-System Freshman } \\
\text { Headcount (Female; Male) }\end{array}$ \\
\hline 2002 & 24 & 917 & 27,466 \\
2003 & $(16 ; 8)$ & $(614 ; 303)$ & $(15,311 ; 12,156)$ \\
28,287 \\
2004 & $(11 ; 8)$ & 971 & $(15,678 ; 12,609)$ \\
& 20 & $(650 ; 321)$ & 28,412 \\
2005 & $(15 ; 5)$ & 998 & $(15,637 ; 12,775)$ \\
& 13 & $(643 ; 355)$ & 29,635 \\
2006 & $(7 ; 6)$ & 925 & $(16,225 ; 13,410)$ \\
& 27 & $(602 ; 323)$ & 29,342 \\
2007 & $(13 ; 14)$ & 1,028 & $(15,727 ; 13,615)$ \\
& 21 & $(672 ; 356)$ & 30,652 \\
2008 & $(10 ; 11)$ & 1,003 & $(16,321 ; 14,331)$ \\
& 18 & $(655 ; 348)$ & 30,329 \\
2009 & $(11 ; 7)$ & 1,017 & $(16,106 ; 14,223)$ \\
& 35 & $(626 ; 391)$ & 30,338 \\
2010 & $(23 ; 12)$ & 1,049 & $(16,056 ; 14,282)$ \\
& $(17 ; 5)$ & $(654 ; 395)$ & 30,257 \\
TOTAL & 194 & 906 & $(15,888 ; 14,369)$ \\
& $(118 ; 76)$ & $(579 ; 327)$ & 264,718 \\
& & 8,814 & $(142,949 ; 121,769)$ \\
\hline
\end{tabular}

Table 2 shows the Number of Hmong Freshman Headcount, Total Freshman Headcount, and Total UW-System Freshman Headcount. From 2002-2010, one hundred ninety $(n=194)$ Hmong students were admitted, enrolled, and attended the university. This is the sampling cohorts by academic years: $2002(n=24), 2003(n=19), 2004(n=20), 2005(n=13), 2006(n=27), 2007$ $(n=21), 2008(n=18), 2009(n=35)$, and $2010(n=17)$. The 2009 cohort has the highest number of Hmong freshman students at thirty-five $(n=35)$ while the lowest cohort is 2005 with thirteen $(\mathrm{n}=23)$ Hmong freshman students. The total number of all freshman students-from 2002-2010 is 8,814 . Hmong freshman students made up about two percent $(0.022 \%)$ of the total-student population from 2002-2010.

Of the one hundred ninety-four $(\mathrm{n}=194)$ Hmong students, one hundred eighteen $(\mathrm{n}=118)$ were females, and seventy-six $(n=76)$ were males (Table 3$)$. Hmong female students comprise of almost sixty-one $(61 \%)$ of the Hmong freshman headcount. Of the nine cohorts, Hmong male students outnumbered Hmong female students in 2007 and 2008. Biggest gender disparity is 2004, with ten Hmong female students and only five Hmong male students. Table 2 shows Number of UW-Green Bay Hmong Freshman Headcount (Female, Male), Total UW-Green Bay Freshman Student Headcount (Female, Male), and Total UW-System Freshman Headcount (Female, Male).

While the traditional tribal clan system still plays a critical role in Hmong communities, we looked at what clans were represented, and how many Hmong students from each clan were represented (Table 4). The clans represented included Cha/Chang ( $\mathrm{n}=2)$, Her $(n=6)$, Kha/Khang $(n=4)$, Kue $(n=3)$, Lee/Ly/Salee $(n=12)$, Lao/Lo/Lor $(n=19)$, Moua $(n=13)$, Thao $(n=23)$, Vang/Lovaj $(n=31)$, Vue $(n=10)$, Xiong/Soung $(n=40)$, and Yang $(n=31)$. Eleven (11) of the eighteen (18) clans were represented. Xiong/Soung clan had the most with forty $(n=40)$ while 
Cha/Chang had the fewest with two $(n=2)$. It is important to note that last names such as Lovaj, Salee, and Soung do not follow traditional Hmong last names, but these students identified themselves as Hmong. Since arriving in the United States, some Hmong families have begun to attach their great, grandfather's name to their last names i.e. Lobliaya, Leebliatou, Vuejongyia, etc.

Table 4. Clans represented and number of students

\begin{tabular}{lc}
\hline Cohort Year & Number of students \\
\hline Cha/Chang & 2 \\
Her & 6 \\
Kha/Khang & 4 \\
Kue & 3 \\
Lee/Ly/Salee & 12 \\
Lao/Lo/Lor & 19 \\
Moua & 13 \\
Thao & 23 \\
Vang/Lovai & 31 \\
Vue & 10 \\
Xiong/Soung & 40 \\
Yang & 31 \\
\hline
\end{tabular}

The students in our studies graduated from 43 high schools (Table 5). The most students came from Green Bay West with 45 (22 females, 23 males). That was followed by Green Bay Preble with 26 (20 females, 6 males) and Green Bay East with 21 ( 14 females, 7 males). Other high schools with notable enrollment include Wausau East ( $n=11,8$ females, 3 males), Wausau West ( $n=10,8$ females, 2 males), DC Everest ( $n=6,4$ females, 2 males), Green Bay Southwest ( $\mathrm{n}=8,7$ females, 1 male) and Sheboygan North ( $\mathrm{n}=8,3$ females, 5 males). 23 high schools have one student. Only one student came from out of state (Minnesota). The Fox Cities with similar Hmong American population as the Green Bay and other surrounding school districts have minimal representation: Appleton $(n=5)$, Kaukauna $(n=0)$, Kimberly $(n=0)$, Menasha $(n=4)$, and Neenah $(n=0)$.

Table 5. High schools represented and number of students

\begin{tabular}{lc}
\hline \multicolumn{1}{c}{ High School } & Number of Students (f/m) \\
\hline Green Bay West & $45(22 / 23)$ \\
Green Bay Preble & $26(20 / 6)$ \\
Green Bay East & $21(14 / 7)$ \\
Wausau East & $11(8 / 3)$ \\
Wausau West & $10(8 / 2)$ \\
DC Everest & $6(4 / 2)$ \\
Green Bay Southwest & $8(7 / 1)$ \\
Sheboygan North & $8(3 / 5)$ \\
23 schools & 1 student \\
\hline
\end{tabular}

With 106 students coming from Green Bay West, Green Bay East, Green Bay Preble, Green Bay Southwest, East De Pere, West De Pere, Bayport, Wrightstown, Denmark, and Notre Dame, almost $55 \%$ of the high school student enrollment came from the greater Green Bay area. Hmong female students out represented Hmong male students from all school districts with the exception 
of Sheboygan North.

To gain a sense of the students' preparation for post-secondary education, we examined their high school cumulative grade point, ACT scores, and college cumulative grade point. The highest student cumulative high school grade point average is 3.93 while the lowest is 2.37 . The highest and lowest ACT scores out of a possible score of 36 are:

- Math: 30;14

- Science: $31 ; 13$

- English: 27;11

- Reading: 30;12

- Composite: 28;13

These are the highest and lowest college cumulative grade point average at UW-Green Bay:

- Highest cum GPA of a graduate from UW-Green Bay: 3.83

- Lowest cum GPA of a graduate from UW-Green Bay: 2.18

- Highest cum GPA of non-graduate from UW-Green Bay with a minimum credit of least 12: 3.83

- Lowest cumulative GPA of non-graduate from UW-Green Bay with a minimum credit of at least 12: 0.78

It is important to note that these academic data, whether high or low, often have little effect on who will or will not graduate from the university. For example, the student with lowest cumulative ACT composite who graduated from UW-Green Bay has a 16/36, and the student with lowest high school cumulative grade point average who graduated from UW-Green Bay has a 2.43. At the end of the spectrum, the student with highest ACT composite who graduated from UWGreen Bay has a 25/36 while the student with highest high school cumulative grade who graduated from UWG has a 3.93/4.0.

\section{Hmong Students' High School Educational Achievement}

High school graduation requirements in the state of Wisconsin include 2 credits in math, 2 credits in science, 4 credits in English, 3 credits in social studies, 1.5 credits in physical education, and at least .5 credit of health education. In addition, "The state superintendent shall encourage school boards to require an additional 8.5 credits in selected from any combination of vocational school, foreign languages, fine arts, and other courses" (DPI, 2016).

To get a clearer picture of the Hmong students' high school performance, we first looked at their high school credits earned in English, Foreign Language, Math, Science, and Social Studies (Table 6). We also looked at their total academic units and high school grade point average (Table 7). We included the average for each academic discipline for each cohort and the total average for each cohort. 
Table 6. High school performance measures for Hmong student cohorts

\begin{tabular}{crrrrrrrr}
$\begin{array}{c}\text { Fall } \\
\text { Cohort }\end{array}$ & English & $\begin{array}{c}\text { Foreign } \\
\text { Language }\end{array}$ & Math & Science & $\begin{array}{c}\text { Social } \\
\text { Studies }\end{array}$ & $\begin{array}{c}\text { Total } \\
\text { Academic }\end{array}$ & HS GPA & N \\
\hline 2002 & 4.1 & 2.5 & 3.6 & 3.5 & 3.9 & 17.6 & 3.2 & 24 \\
2003 & 4.2 & 2.0 & 3.5 & 3.5 & 3.7 & 16.8 & 3.2 & 19 \\
2004 & 4.2 & 2.7 & 3.5 & 3.5 & 3.7 & 17.5 & 3.1 & 20 \\
2005 & 4.2 & 2.7 & 3.4 & 3.8 & 4.1 & 18.1 & 3.3 & 13 \\
2006 & 4.2 & 2.7 & 3.5 & 3.5 & 3.7 & 17.5 & 3.1 & 27 \\
2007 & 4.0 & 2.8 & 3.6 & 3.6 & 3.6 & 18.1 & 3.2 & 21 \\
2008 & 3.9 & 2.6 & 3.7 & 3.8 & 3.6 & 17.6 & 3.2 & 18 \\
2009 & 4.1 & 2.8 & 3.7 & 3.4 & 3.9 & 18.4 & 3.1 & 35 \\
2010 & 4.1 & 2.9 & 3.7 & 4.4 & 4.2 & 19.3 & 3.3 & 17 \\
ALL & 4.1 & 2.7 & 3.6 & 3.8 & 3.8 & 18.0 & 3.2 & 194 \\
\hline
\end{tabular}

There is no noticeable difference between the two groups of students in these measures over the nearly ten-year period. First-year students entering the university have taken, on average, 2.7 units of foreign language, 3.6 units of math, and 3.8 units of science, and 3.8 units of social studies. Their high school GPA (grade point average) is 3.2 on the standard 4-point scale. Overall, the Hmong students' scores on these seven measures are similar to that of all first-year students.

Table 7. High school performance measures for all first-year student cohorts

\begin{tabular}{crrrrrrrr}
\hline Fall Cohort & English & $\begin{array}{c}\text { Foreign } \\
\text { Language }\end{array}$ & Math & Science & $\begin{array}{c}\text { Social } \\
\text { Studies }\end{array}$ & Total Academic HS GPA & N \\
\hline 2002 & 4.2 & 2.7 & 3.9 & 3.8 & 3.8 & 18.3 & 3.2 & 917 \\
2003 & 4.2 & 2.8 & 4.0 & 3.8 & 3.8 & 18.5 & 3.2 & 971 \\
2004 & 4.2 & 2.8 & 3.9 & 3.8 & 3.9 & 18.6 & 3.1 & 998 \\
2005 & 4.2 & 2.8 & 3.9 & 3.8 & 3.8 & 18.6 & 3.3 & 925 \\
2006 & 4.2 & 2.8 & 3.8 & 3.7 & 3.6 & 17.9 & 3.1 & 1,028 \\
2007 & 4.0 & 2.8 & 3.8 & 3.6 & 3.7 & 18.0 & 3.2 & 1,003 \\
2008 & 4.0 & 2.8 & 3.8 & 3.7 & 3.8 & 17.9 & 3.2 & 1,017 \\
2009 & 4.1 & 2.9 & 3.8 & 3.8 & 3.8 & 18.0 & 3.1 & 1,049 \\
2010 & 4.1 & 2.9 & 3.9 & 3.8 & 3.9 & 18.4 & 3.3 & 906 \\
ALL & 4.1 & 2.7 & 3.6 & 3.8 & 3.8 & 18.0 & 3.2 & 8,814 \\
\hline
\end{tabular}

Next, we compared ACT scores for Hmong students and all first-year students entering the university (Table 8). Two results stand out in this table: first, the ACT scores are generally consistent across the cohorts of Hmong and all first-year students, although there is more variance (but no upward or downward trend) for Hmong students; second, unlike the high school academic measures, Hmong students' overall ACT scores are well below that of ALL- UW-Green Bay students. On average, the Hmong students' scores in their ACT composite, ACT English, ACT Math, ACT Science, and ACT Reading are two points less than that of ALL- UW-Green Bay students. 
Table 8. ACT scores (Hmong students and All UWGB student cohorts)

\begin{tabular}{ccccccccccc}
\hline $\begin{array}{c}\text { Fall } \\
\text { Cohort }\end{array}$ & \multicolumn{2}{c}{ Composite } & \multicolumn{2}{c}{ English } & \multicolumn{2}{c}{ Math } & \multicolumn{2}{c}{ Reading } & \multicolumn{2}{c}{ Science } \\
& Hmong & $\begin{array}{c}\text { All } \\
\text { UWGB }\end{array}$ & Hmong & $\begin{array}{c}\text { All } \\
\text { UWGB }\end{array}$ & Hmong & $\begin{array}{c}\text { ALL } \\
\text { UWGB }\end{array}$ & Hmong & $\begin{array}{c}\text { All } \\
\text { UWGB }\end{array}$ & Hmong & $\begin{array}{c}\text { All } \\
\text { UWGB }\end{array}$ \\
\hline 2002 & 19.4 & & 17.8 & & 20.1 & & 19.1 & & 20.4 & \\
2003 & 18.4 & & 16.2 & & 19.6 & & 18.5 & & 19.1 & \\
2004 & 18.5 & & 16.8 & & 18.7 & & 19.3 & & 19.2 & \\
2005 & 18.9 & 22.7 & 16.9 & 22.3 & 19.3 & 22.6 & 19.2 & 23.3 & 20.6 & 22.9 \\
2006 & 18.5 & 22.6 & 16.8 & 22.1 & 18.7 & 22.3 & 19.3 & 23.2 & 19.2 & 22.7 \\
2007 & 19.3 & 22.5 & 18.2 & 22.0 & 20.6 & 22.3 & 18.5 & 23.1 & 20.6 & 22.8 \\
2008 & 19.8 & 22.4 & 18.4 & 21.9 & 20.9 & 22.2 & 19.1 & 23.0 & 21.4 & 22.7 \\
2009 & 19.1 & 22.4 & 17.9 & 21.9 & 20.1 & 22.2 & 18.4 & 22.8 & 20.3 & 22.6 \\
2010 & 20.3 & 22.9 & 18.4 & 22.5 & 21.9 & 22.7 & 19.5 & 23.4 & 21.2 & 23.0 \\
\hline
\end{tabular}

The measures of student performance in high school (academic credit units and ACT scores) give us an opportunity to look at what factors might explain the Hmong students' GPA and ACT scores. In Table 9 we examine the correlation between high school GPA and the number of education units completed during the student's high school career. We would expect the strongest correlations between high school GPA and the number of math and science units completed, as the second-level math and science courses would ordinarily be taken by students with higher grades. Table 9 shows a moderate correlation and statistically significant relationships between the number of education units completed in language, math, and science and high school GPA.

Table 9. Correlation between high school GPA and number of education units completed

\begin{tabular}{lllllll}
\hline & GPA & English & Language & Math & Science & Social \\
\hline GPA & & & & & & \\
English & 0.047 & & & & & \\
Language & $0.260^{* *}$ & 0.046 & & & & \\
Math & $0.253^{* *}$ & 0.085 & & & \\
Science & $0.243^{* *}$ & 0.109 & $0.237^{*}$ & $0.229^{* *}$ & & \\
Social & 0.079 & $0.238^{* *}$ & 0.052 & 0.086 & 0.124 & \\
\hline
\end{tabular}

** Correlation is significant at the 0.01 level

*Correction is significant at the 0.05 level

Table 10 shows the relationship between the students' overall ACT score and individual subject scores. There are strong and statistically significant correlations between the scores for individual subject areas and between the subject area scores and the overall ACT score.

Table 10. Correlation among ACT subject scores for Hmong students

\begin{tabular}{llllll}
\hline & ACT & Math & Reading & Science & English \\
\hline ACT & & & & & \\
Math & $0.746^{* *}$ & & & & \\
Reading & $0.798^{* *}$ & 0.375 & & & \\
Science & $0.777^{* *}$ & 0.582 & 0.503 & & \\
English & $0.790^{* *}$ & $0.438^{* *}$ & $0.592^{* *}$ & $0.474^{* *}$ & \\
\hline
\end{tabular}

** Correlation is significant at the 0.01 level

*Correction is significant at the 0.05 level 


\section{Hmong Students' College Educational Achievement}

There are a number of measures commonly used to assess college performance. Table 11 reports on the number of terms enrolled at UW-Green Bay, credits completed in the first term, total credits completed at UW-Green Bay, first semester GPA, and final cumulative GPA while at UWGreen Bay. We found that there is more variance across the cohorts in these measures than what we found in the high school performance measures. For example, the number of fall and spring terms enrolled and not withdrawn ranges from 5.2 (for the 2010 cohort) to 7.8 (for the 2005 cohort), and the number of credits completed in the first term ranges from 7.7 (for the 2005 cohort) to 10.7 (for the 2002 cohort). There does not appear to be a trend from the earlier to more recent cohorts, rather a good deal of variance from one year to the next.

Table 11. College performance for Hmong student cohorts

\begin{tabular}{ccrrrrr}
\hline Fall & $\begin{array}{c}\text { Number of Fall } \\
\text { and Spring Terms } \\
\text { Enrolled and not } \\
\text { Withdrawn }\end{array}$ & $\begin{array}{c}\text { Credits } \\
\text { Completed in } \\
\text { Cohort }\end{array}$ & $\begin{array}{c}\text { First Term } \\
\text { Semester } \\
\text { GPA }\end{array}$ & $\begin{array}{c}\text { Total Credits } \\
\text { Completed }\end{array}$ & $\begin{array}{c}\text { Final } \\
\text { Cumulative } \\
\text { GPA }\end{array}$ & $\begin{array}{c}\text { No of } \\
\text { Students }\end{array}$ \\
\hline 2002 & 6.4 & 10.7 & 2.5 & 77.5 & 2.5 & 24 \\
2003 & 6.7 & 7.8 & 2.2 & 77.7 & 2.4 & 19 \\
2004 & 6.1 & 8.4 & 2.5 & 70.9 & 2.3 & 20 \\
2005 & 7.8 & 7.7 & 2.2 & 76.6 & 2.3 & 13 \\
2006 & 6.6 & 9.0 & 2.6 & 77.0 & 2.6 & 27 \\
2007 & 7.4 & 9.7 & 2.4 & 87.5 & 2.3 & 21 \\
2008 & 7.2 & 9.2 & 2.2 & 90.4 & 2.3 & 18 \\
2009 & 5.8 & 10.0 & 2.3 & 71.5 & 2.4 & 35 \\
2010 & 5.2 & 9.9 & 2.4 & 63.6 & 2.4 & 17 \\
ALL & 5.7 & 9.8 & 2.4 & 66.4 & 2.4 & 194 \\
\hline
\end{tabular}

The average first semester GPA is 2.4 (with little variation across the cohorts) and the final GPA at UW-Green Bay is also 2.4 (again with little variance across cohorts). The GPA measures are 0.8 points lower than high school GPAs for the Hmong students, similar to what is found for college students as a whole, where the college GPA is generally one point lower than the high school GPA.

For our first analysis of the college academic data we have, we looked to see if there is any correlation between their college GPA and other variables such as their high school GPA, ACT composite, and subject scores. Table 12 shows our results of the correlation between their college GPA and their high school GPA, ACT composite and subject scores. The student's first semester GPA is most strongly correlated with high school GPA and with ACT math and ACT composite scores. The students' cumulative GPA is strongly correlated with first semester GPA and with high school GPA. It is interesting to note that the performance of Hmong students at UW-Green Bay is not strongly related to ACT scores but rather to their performance in high school (as measured by high school GPA). 
Table 12. Correlation between high school GPA, ACT subject scores, ACT composite score, first semester college GPA, and cumulative college GPA for Hmong students

\begin{tabular}{|c|c|c|c|c|c|c|c|c|}
\hline & HS GPA & Reading & Math & Science & English & $\begin{array}{l}\text { ACT } \\
\text { Comp }\end{array}$ & $\begin{array}{c}\text { FS } \\
\text { GPA }\end{array}$ & $\begin{array}{c}\text { CUM } \\
\text { GPA }\end{array}$ \\
\hline HS GPA & & & & & & & & \\
\hline Reading & $0.254 * * * *$ & & & & & & & \\
\hline Math & $0.341 * * *$ & $0.363 * *$ & & & & & & \\
\hline Science & $0.344 * *$ & $0.472 * *$ & $597 * *$ & & & & & \\
\hline English & $0.307 * *$ & $0.576 * *$ & $445 * *$ & $0.454 * *$ & & & & \\
\hline ACT Comp & $0.395 * *$ & $0.787 * *$ & $752 * *$ & $0.768 * *$ & $0.787 * *$ & & & \\
\hline FS GPA & $0.298 * *$ & 0.125 & $228 * *$ & $0.200 * *$ & $0.159 * *$ & $0.239 * *$ & & \\
\hline CUM GPA & $0.372 * *$ & $0.147 *$ & $189 *$ & $0.206 * *$ & $0.260 * *$ & $0.260 * *$ & $0.659 * *$ & \\
\hline
\end{tabular}

** Correlation is significant at the 0.01 level

*Correction is significant at the 0.05 level

While earlier tables show correlations between their first semester and cumulative college and high school GPA, high school completion credits, ACT composite and subject scores, we would expect significant interaction effects among these variables and need to sort out the independent effects of each measure and of each group of measures.

Table 13 allows us to do that by showing the results of five different regression analyses used to explain college performance (as measured by cumulative GPA). In the first column, college GPA is regressed against ACT subject area scores; the amount of variance explained these four variables (shown by the R Square) is minimal (0.074). The second column shows the effect of high school credits completed in English, language, social studies, math, and science on college performance (Cumulative GPA); the amount of variance explained by these variables is again minimal. Column 4 presents the results of both sets of variables (number of high school credits completed and ACT subject area scores) on college performance (again measured by cumulative college GPA); once again the amount of variance explained is minimal (0.057).

Table 13. What explains college success (GPA) for Hmong students? (Cumulative GPA while at UWGB

\begin{tabular}{crrrrr} 
& $\begin{array}{c}\text { College } \\
\text { GPA }\end{array}$ & $\begin{array}{c}\text { HS Credits } \\
\text { Completed }\end{array}$ & HS GPA & $\begin{array}{c}\text { HS Credits } \\
\text { Completed \& ACT } \\
\text { Subject Area Scores }\end{array}$ & $\begin{array}{c}\text { ACT Subject Area } \\
\text { Scores \& HS Credits } \\
\text { Completed }\end{array}$ \\
\hline ACT English & 0.201 & & & 0.221 & 0.151 \\
ACT Reading & -0.038 & & & -0.044 & -0.046 \\
ACT Math & 0.051 & & & 0.081 & 0.04 \\
ACT Science & 0.096 & & & 0.088 & 0.064 \\
HS English & & -0.078 & -0.011 & -0.063 & -0.012 \\
HS Language & & 0.093 & 0.012 & 0.064 & 0.006 \\
HS Social Studies & & 0.128 & 0.113 & 0.145 & -0.126 \\
HS Math & & 0.002 & -0.067 & -0.073 & -0.1 \\
HS Science & & -0.027 & -0.085 & & -0.082 \\
& & & & & 0.329 \\
HS GPA & & & 0.395 & & 0.137 \\
R Square & 0.074 & -0.002 & 0.131 & & \\
\hline
\end{tabular}


In the two remaining columns (third and fifth columns in the table above), High School GPA has been added to the regression models that include high school credits completed, and the combined ACT Subject area scores and high school credits completed. These models as well show only small amount of variance explained (0.131 and 0.137) but it is important to note that High School GPA is the only variable in these models that has a strong impact on cumulative college GPA. Clearly we need to look at other variables-such as student work activity, family background, education experience of siblings, and other factors to gain a better understanding of college careers and college success.

\section{Hmong Students' Post-Secondary Educational Outcomes}

Of the one hundred ninety-four ( $\mathrm{n}=194)$ students who were admitted and attended UW-Green Bay in the 2002-2010 cohorts, seventy (36.1 percent) went on to graduate from the university. Another thirteen (6.7 percent) transferred to and had graduated from another four-year college or university within the five-year period after admittance. A slightly smaller number (12 students, or 6.2 percent) had transferred and graduated from two year schools. More than a quarter were still enrolled in a two or four-year school, including 22 students (11.3 percent) at UW-Green Bay and another 33 (17.0 percent) at other two- or four-year institutions. Table 14 shows the academic statuses of all of the one hundred ninety-four Hmong student cohorts from 2002-2010.

Table 14. Current status for Hmong student cohorts attending UWGB 2002-2010

\begin{tabular}{crrrrrr}
\hline Fall Cohort & Admitted & $\begin{array}{c}\text { Graduated } \\
\text { UWGB }\end{array}$ & $\begin{array}{c}\text { Currently } \\
\text { Enrolled } \\
\text { UWGB }\end{array}$ & $\begin{array}{c}\text { Graduated } \\
\text { Other 4- } \\
\text { Year }\end{array}$ & $\begin{array}{c}\text { Graduated } \\
\text { Other 2- } \\
\text { Year }\end{array}$ & $\begin{array}{c}\text { Currently } \\
\text { Enrolled } \\
\text { Elsewhere }\end{array}$ \\
\hline 2002 & 24 & 11 & 0 & 2 & 3 & 2 \\
2003 & 19 & 8 & 1 & 1 & 2 & 0 \\
2004 & 20 & 7 & 0 & 4 & 2 & 1 \\
2005 & 14 & 6 & 0 & 1 & 0 & 3 \\
2006 & 26 & 12 & 1 & 5 & 1 & 3 \\
2007 & 21 & 13 & 0 & 0 & 2 & 3 \\
2008 & 18 & 7 & 4 & 0 & 1 & 4 \\
2009 & 35 & 6 & 11 & 0 & 1 & 7 \\
2010 & 17 & 0 & 5 & 0 & 0 & 20 \\
Female & 118 & 47 & 11 & 7 & 10 & 13 \\
Male & 76 & 23 & 11 & 6 & 2 & 33 \\
ALL & 194 & 70 & 22 & 13 & 12 & 2 \\
\hline
\end{tabular}

Table 15. High schools and number of graduates

\begin{tabular}{lc}
\hline High School & Number of Graduates \\
\hline Green Bay West & 16 \\
Green Bay Preble & 10 \\
Green Bay East & 10 \\
Wausau East & $6(1)^{* * *}$ \\
Wausau West & 6 \\
DC Everest & 5 \\
Green Bay Southwest & 3 \\
\hline
\end{tabular}

***One graduated from another institution 
Delving deeper into the number of graduates, Green Bay West has the most number of college graduates with 16, which is $35.5 \%$ of all students from Green Bay West. That is followed by Green Bay Preble with 10, Green Bay East with 10, Wausau East with seven and one graduated from another UW-institution, Wausau West with six, DC Everest with five, and Southwest with three. For high schools with at least five UW-Green Bay graduates, DC Everest has the highest percentage of students matriculating and graduating from UW-Green Bay, five out of six (83\%). Table 15 captures these numbers.

Table 16 shows the degree completions at the university by gender with 47 of the graduates being females and 23 being males. Adding 13 graduates from other UW colleges and universities brings the total female graduates to 54 and male graduates to 29 . The number of enrolled Hmong female students in the 2002- 2010 cohorts is 118 and the male cohorts is 76. The percentage of Hmong female students graduating from UW-Green Bay is $39.8 \%$ and the percentage of Hmong male students graduating from UW-Green Bay is $30.3 \%$.

Table 16. Post-secondary outcomes for Hmong student cohorts attending UWGB 2002-2010

\begin{tabular}{|c|c|c|c|c|c|c|}
\hline $\begin{array}{l}\text { Fall Cohort } \\
\text { by Gender }\end{array}$ & Admitted & $\begin{array}{l}\text { Graduated at } \\
\text { UWGB }\end{array}$ & $\begin{array}{l}\text { Currently } \\
\text { Enrolled at } \\
\text { UWGB }\end{array}$ & $\begin{array}{c}\text { Graduated } \\
\text { Other 4-Year }\end{array}$ & $\begin{array}{c}\text { Graduated } \\
\text { Other 2-Year }\end{array}$ & $\begin{array}{c}\text { Currently } \\
\text { Enrolled } \\
\text { Elsewhere }\end{array}$ \\
\hline 2002 female & 16 & 8 & 0 & 0 & 3 & 1 \\
\hline 2002 male & 8 & 3 & 0 & 2 & 0 & 1 \\
\hline 2002 Total & 24 & 11 & 0 & 2 & 3 & 2 \\
\hline 2003 female & 11 & 7 & 0 & 1 & 0 & 0 \\
\hline 2003 male & 8 & 1 & 1 & 1 & 2 & 0 \\
\hline 2003 Total & 19 & 11 & 1 & 2 & 2 & 0 \\
\hline 2004 female & 15 & 5 & 0 & 4 & 2 & 0 \\
\hline 2004 male & 5 & 2 & 0 & 0 & 0 & 1 \\
\hline 2004 Total & 20 & 7 & 0 & 4 & 2 & 1 \\
\hline 2005 female & 7 & 4 & 0 & 1 & 0 & 1 \\
\hline 2005 male & 6 & 2 & 0 & 0 & 0 & 2 \\
\hline 2005 Total & 13 & 6 & 0 & 1 & 0 & 3 \\
\hline 2006 female & 13 & 7 & 1 & 2 & 1 & 0 \\
\hline 2006 male & 14 & 5 & 0 & 3 & 0 & 3 \\
\hline 2006 Total & 27 & 12 & 1 & 5 & 1 & 3 \\
\hline 2007 female & 10 & 7 & 0 & 0 & 2 & 1 \\
\hline 2007 male & 11 & 6 & 0 & 0 & 0 & 2 \\
\hline 2007 Total & 21 & 13 & 0 & 0 & 2 & 3 \\
\hline 2008 female & 11 & 4 & 2 & 0 & 1 & 3 \\
\hline 2008 male & 7 & 3 & 2 & 0 & 0 & 1 \\
\hline 2008 Total & 18 & 7 & 4 & 0 & 1 & 4 \\
\hline 2009 female & 23 & 6 & 6 & 0 & 1 & 7 \\
\hline 2009 male & 12 & 1 & 5 & 0 & 0 & 3 \\
\hline 2009 Total & 35 & 7 & 11 & 0 & 1 & 10 \\
\hline 2010 female & 12 & 0 & 2 & 0 & 0 & 7 \\
\hline 2010 male & 5 & 0 & 3 & 0 & 0 & 0 \\
\hline \multirow[t]{2}{*}{2010 Total } & 17 & 0 & 5 & 0 & 0 & 7 \\
\hline & $\mathrm{F}=118$ & $\mathrm{~F}=47$ & $\mathrm{~F}=11$ & $\mathrm{~F}=7$ & $\mathrm{~F}=10$ & $\mathrm{~F}=20$ \\
\hline GRAND & $M=76$ & $M=23$ & $M=11$ & $M=6$ & $M=2$ & $M=13$ \\
\hline TOTAL & $\mathrm{T}=194$ & $\mathrm{~T}=70$ & $\mathrm{~T}=22$ & $\mathrm{~T}=13$ & $\mathrm{~T}=12$ & $\mathrm{~T}=33$ \\
\hline
\end{tabular}

Finally, we examined the years to degree completion for UW-Green Bay Hmong graduates and ALL UW-Green Bay students. 
- For Hmong students, the average years to degree completion for Hmong students is 5.21.

- The fewest years to degree completion is four with 13 students.

- The most years to degree completion is 11.5 with one student.

- The five years to Degree Completion has the most Hmong student graduates with twenty $(n=20)$.

- For four years to degree completion, there were zero male Hmong students.

- The six years to degree completion is the only category (that has two more graduates) that has more male Hmong graduates than female Hmong graduates.

- For all students who entered the university, 22.8\% of the 2002-2010 cohorts completed their degree at the end of their fourth year.

- $46 \%$ of fifth year students completed their degree at the end of their fifth year.

- $50.8 \%$ of sixth year students completed their degree at the end of their sixth year, and

- $52.7 \%$ of seventh year students completed their degree at the end of their seventh year.

\section{Conclusions}

As the Hmong National Development reported, Hmong American educational attainment lags behind that of Whites, Hispanics, and other minority groups. But with the increasing number of Hmong young adults entering and completing college, as shown in this study and others (such as Xiong (2012), the percentage of Hmong American with a college degree should increase in the next census report. The question is by how much?

Vue (2008), Lee (1997) and Lor (2013) provide insights about Hmong women's lack of educational opportunity before arriving in the United States and their academic progress since then. The data presented here, with 54 female Hmong graduates out of 116 enrolled as compared to 29 male Hmong graduates out of 76 enrolled, shows Hmong women are making progress, outpacing Hmong males in matriculation as well as graduation. Thao (2015) also reports a similar gender disparity in his study of Hmong college students at Sacramento State University, with $61.7 \%$ of Hmong graduates being female. Will this trend continue? If it does, how will the gender achievement disparity be addressed? What impact will this have on gender roles and traditional Hmong culture more generally?

Our data and analysis suggest important differences in Hmong students' educational achievement compared with other students. Hmong students on average have lower high school grade point averages and lower ACT scores than other students; however, in the end, their college GPA and overall academic success is comparable to that of other students in their cohort. This is a good sign for Hmong students. Is similar academic trend occurring at other institutions where there are a significant number of Hmong student enrollment?

In the last decade, a growing number of Hmong scholars as well non-Hmong scholars have focused their research on the Hmong college student experience. Thao (2015), Saloka (2014), Iannarelli (2014), and Xiong and Lam (2013) explore life experiences affecting Hmong college students' educational attainment, reporting factors include parents, teachers, friends, students' own motivation and expectations, and various educational services all played a role. Lo (2013) specifically analyzes Hmong parental influences on Hmong students' decisions to matriculate and concludes that Lee (2014) reports on the academic characteristic of 238 freshmen at Western University in California and shares that the Hmong students do not share characteristics of a "model minority." Vang (2015) examines how Hmong college students who are mothers utilize familial 
resources, shifting in opportunities for women, and institutional resources to navigate college. The research trajectory on the Hmong college experience looks promising.

\section{Implications for Practice}

Our main aim in our study was to get clarity on the educational achievement and outcomes of Hmong students admitted to and entering UW-Green Bay from 2002-2010. We have done so by exploring and analyzing the demographic characteristics, high school educational achievement, college educational achievement and their post-secondary educational outcomes of the 194 students in our sample.

Accordingly, one of our major findings is that while there is a substantive difference in the SAT scores of Hmong and other first-year students entering college, the ACT does not appear to predict educational performance at the college level and is not associated with graduation from college. This has major implications for Hmong high school students applying to college, who may be disappointed in their ACT scores; guidance counselors should let the students know that the ACT is an imperfect predictor of later educational performance, and encourage the students to apply to four-year colleges and universities if they have sought this path. This result has important implications for college admissions as well, as we know that Hmong students applying to college may have ACT scores lower than that of other students, but are equally likely to do well and graduate once they have entered college.

A second finding of the study is the large gap of post-secondary educational outcomes between female Hmong students and male Hmong students. Anecdotal information from the Hmong communities, personal observations of academic achievement among Hmong males and females, and research from other Hmong scholars also support this widening gap. Our results are important in that both Hmong and non-Hmong educators, community leaders, and organizations will need to examine and find the sources that are causing such dynamic, gender gap and if need be, must be willing to implement solutions or make policy or cultural changes to narrow the gap. If the gap persists or widens, this can bring unintended consequences for future Hmong communities and generations: gender inequity in educational achievement, gender inequity in social and financial capita, and gender inequity in political and cultural infrastructures.

There are two results from our study that may have an important bearing on campus climate. The majority of Hmong students matriculating at UW-Green Bay mainly came from one geographical area: the greater Green Bay area. Critical experiences of going college include diversifying a student's life experiences and providing students with opportunities to build and establish networks with other students of various backgrounds with the aim that they will expand a student's horizon, knowledge, and capacity to navigate a diverse world. This includes meeting and interacting with other Hmong students from other parts of the state and out of state. In other words, though Hmong students may share a common history with students from Hmong communities in other parts of the state or out of state, their life experiences will be different. All students, Hmong or otherwise, need interactions with students from other parts of the state as well as outside to diversify their perspectives. Local campuses and the UW-System more generally need to recognize and value this cultural dimension of the Hmong college student experience and find ways to promote such diversity among Hmong students.

Finally, we were disappointed to see the large number of Hmong students who transferred

or dropped out. Finding out what caused them to drop out or transfer could help university 
minority student services programs, academic services, or outreach programs to improve their efforts, services, and policies to retain and graduate Hmong college students.

\section{Implications for Future Research}

Our study, exploratory in nature and limited by data and institution, raises a number of opportunities for future research, and for both qualitative and quantitative studies. Future research on the Hmong student educational achievement will only refine and add depth to our research methods and findings about the Hmong college student experience.

First, our analysis of data came from one institution. Our study protocols can be duplicated or modified to study other similar comprehensive institutions as well as community colleges and technical colleges that serve Hmong students. The findings from such additional studies, whether they are on single or multiple institutions, will surely shed more light and add more substance about the Hmong student's educational achievement.

Second, a qualitative study examining other variables, beyond the academic data in our study, will add different perspectives and dimensions to the Hmong student college experience, particularly a phenomenological, qualitative study that examines the students' own perspectives on their college experience. Such findings will add a more humane dimension and further legitimize the essence of their college experience.

Lastly, there are potential, longitudinal studies that could be done with our sampling or of other similar samplings. For example, a longitudinal study, following up on our sampling for a period of five, 10, 15, and 20 years, examining various aspects and dynamics of their lives, could provide insights into whether or not their investment in a college education has paid social, financial, and cultural dividends. Such findings will show the full measure of a college education for the individual and for the community as a whole.

\section{References}

Department of Public Instruction (2016). Graduation. Retrieved from http://dpi.wi.gov/graduation.

DePouw, C. (2003). Familiar foreign: Hmong American students engaging and resisting America. Champaign, IL: University of Illinois at Urbana-Champaign.

DePouw, C. (2006). Negotiating race, navigating school: Situating Hmong American university student experiences. PhD Dissertation, Champaign, IL: University of Illinois at UrbanaChampaign.

DePouw, C. (2012). When culture implies deficit: Placing race at the center of Hmong American education. Race Ethnicity and Education, 15(2), 223-229.

Goldstein, B.L. (1985). Schooling for cultural transitions: Hmong girls and boys in American high schools. (Ph.D. Dissertation), Madison, WI: University of Wisconsin.

Hamilton-Merritt, J. (1999). Tragic Mountains: The Hmong, the Americans, and the secret wars for Laos, 1942-1992. Bloomington, IN: Indiana University Press.

Hendricks, G. L., Downing, B. T., \& Deinard, A.S. (1986). The Hmong in transition. New York, NY: Center for Migration Studies.

Hillmer, P. (2010). A people's history of the Hmong. St. Paul, MN: Minnesota Historical Society Press. 
Hmong National Development, (2003). Hmong 2000 census publication: Data and analysis. Washington, D.C: Author

Hmong National Development, (2013). State of the Hmong American community. Retrieved from http://www.vuenational.org/wp-content/uploads/2013/05/State-of-the-Hmong-AmericanCommunity-2013.pdf

Hoeffel, E. M., S. Rastogi, M. O. Kim, \& H. Shahid, (2012). The Asian American population: 2010 census briefs. Retrieved from https://www.census.gov/prod/cen2010/briefs/c2010br11.pdf

Hutchison, R. (1997). The educational performance of Hmong students in Wisconsin. Thiensville, WI: Wisconsin Policy Research, Inc.

Iannarelli, C. M. (2014). Stressing success: Examining Hmong student success in career and technical education. Hmong Studies Journal, 15(1), 1-22.

Koltyk, J. A. (1997). New pioneers in the heartland: Hmong life in Wisconsin. Boston, MA: Allyn and Bacon.

Lee, F. M. (2014). Academic characteristics of 2009 first-time freshmen Hmong college students at a western university. Retrieved from

https://repository.library.fresnostate.edu/bitstream/handle/10211.3/105376/FaithLEEpdfA. pdf? sequence $=1$

Lee, S. J. (1997). The Road to college: Hmong American women's pursuit of higher education. Harvard Education Review, 67(4), 803-828.

Lo, O. (2013). Parental influence on Hmong students' decisions towards higher education. Master's Thesis, UW-Stout. Retrieved from http://www2.uwstout.edu/content/lib/thesis/2013/2013loo.pdf

Long, L. (1993). Ban Vinai, the refugee camp. New York, NY: Columbia University Press.

Lor, P. (2013). A Hmong professional woman's reflections and perspectives on the influences affecting the changing roles of Hmong women in America. Journal of Cultural Diversity, 20(1), 40-48.

Lor, P. (2009). A photo essay of the Hmong experience at Wat Thamkrabok in Thailand. Hmong Studies journal, 9, 1-41.

Lor, P. (2008). Key life experiences contributing to Hmong students' matriculation. Multicultural Education, 16(1), 39-47.

National Center for Educational Statistics (2016). Time to degree. Retrieved from https://nces.ed.gov/fastfacts/display.asp?id=569

Ngo, B. (2000). Obstacles, miracles, and the pursuit of higher education: The experiences of Hmong American college students. Master's Thesis, Madison, WI: University of Wisconsin.

Pfeifer, M. Chiu, M., \& Yang, K. (2013). Diversity in diaspora: Hmong Americans in the twentyfirst century. Honolulu, HI: University of Hawaii Press.

Saloka, O. G. (2014). Successful first-generation Hmong college students' descriptions of their educational experiences in Minnesota. Doctoral dissertation, Winona, MN: Saint Mary's University of Minnesota.

Thao, P. (2015). Hmong students' life experiences that affect affectional attainment. Doctoral dissertation, Stanislaus, CA: California State University, Stanislaus.

Vang, C. T. (2001). Histories and academic profiles of successful and unsuccessful Hmong secondary students. Ph.D. dissertation, Davis and Fresno, CA: California State of University. 
Vang, C. T. (2003). Learning more about Hmong students. Multicultural Education, 1l(2), 10-14. Vang, C. T. (2004). Hmong American K-12 students and the academic skills needed for a college education: A review of the existing literature and suggestions for future research. Hmong Studies Journal 5, 1-31.

Vang, C. T. (2005). Hmong-American students still face multiple challenges in public schools. Multicultural Education, 13(1), 27-35.

Vang, H. (2015). Young Hmong mothers' attainment of higher education: Using familial, cultural, and institutional resources. Master Thesis, Fresno, CA: California State University.

Vue, P.P. (2008). Factors that contribute towards and/or impede Hmong women from obtaining a higher education degree. Dissertation Abstracts International Section A: Humanities and Social Science, 68(8-1).

Xiong, S., \& Lam, S. K. (2013). Factors affecting the success of Hmong college students in America. British Journal of Guidance \& Counselling, 41(2), 132-144.

Xiong, Y.S. (2012). Hmong Americans' educational attainment: Recent changes and remaining challenges. Hmong Studies Journal, 13(2), 1-18.

Yang, D. (1993). Hmong at turning point. Minneapolis, MN: World Bridge Associates. 


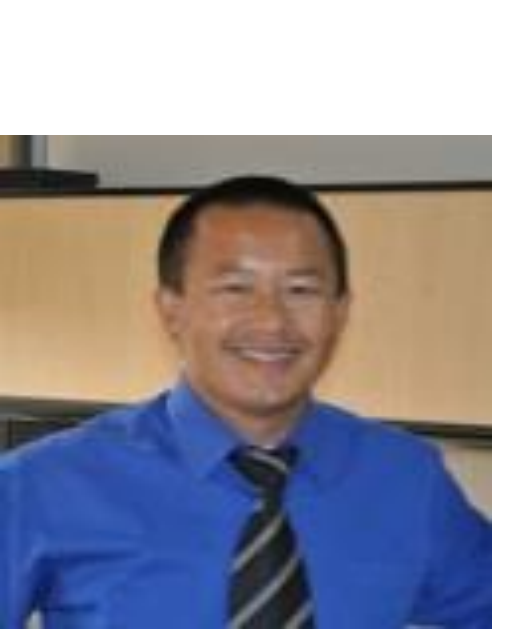

\section{About the Authors}

Pao Lor is an associate professor in education in the College of Health, Education and Social Welfare at the University of Wisconsin-Green Bay. His professional interests are the Hmong American educational experience, teacher preparation programs, and educational leadership.

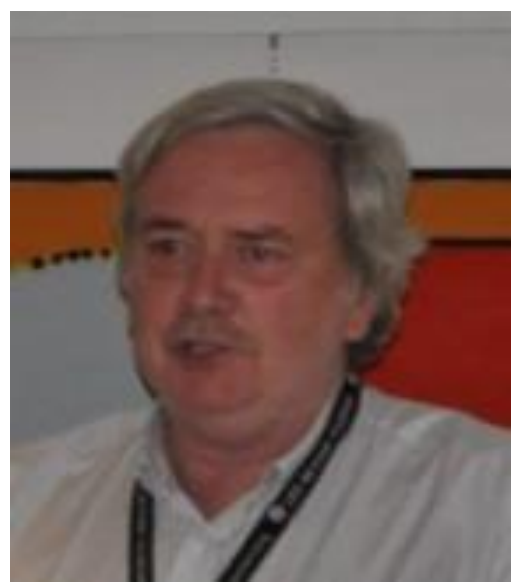

Ray Hutchison is professor of sociology in Public and Environmental Affairs at the University of WisconsinGreen Bay, where he is Director of the Hmong Studies Center. In addition to his published work on Hmong education and language use, he is editor of the Encyclopedia of Urban Studies (SAGE) and other books. 


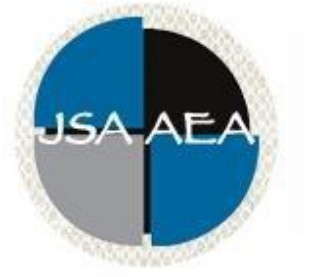

Vol. 12 Iss. 1 (2017)
www.JSAAEA.org

Editor

Dr. Wayne E. Wright

Purdue University

Associate Editors

Dr. Chhany Sak-Humphry

University of Hawaii at Manoa

Dr. Phitsamay Sychitkokhong Uy

University of Massachusetts, Lowell

\author{
Book Review Editor \\ Dr. Vichet Chhuon \\ University of Minnesota \\ Creative Works Editor \\ Bryan Thao Worra \\ Lao Assistance Center \\ Journal Manager \\ Sung Ae Kim \\ Purdue University
}

\section{Editorial Review Board}

Dr. Steve Arounsack

California State University, Stanislaus

Dr. Sovicheth Boun

The State University of New York, Fredonia

Dr. George Chigas

University of Massachusetts, Lowell

Dr. Hien Duc Do

San Jose State University
Dr. Carl L. Bankston III

Tulane University

Dr. Angela Reyes

Hunter College, The City University of New

York

Dr. Loan Dao

University of Massachusetts, Boston

Dr. Changming Duan

University of Missouri, Kansas City 


\author{
Dr. Sophal Ear \\ Occidental College \\ Dr. Virak Chan \\ University of Texas at San Antonio \\ Dr. Nancy H. Hornberger \\ University of Pennsylvania \\ Dr. Peter Nien-Chu Kiang \\ University of Massachusetts, Boston \\ Dr. Ha Lam \\ Eastern Mennonite University \\ Dr. Jonathan H. X. Lee \\ San Francisco State University \\ Dr. Monirith Ly \\ Royal University of Phnom Penh \\ Dr. Bic Ngo \\ University of Minnesota \\ Dr. Leakhena Nou \\ California State University, Long Beach \\ Dr. Mark Pfeifer \\ SUNY Institute of Technology \\ Dr. Loan T. Phan \\ University of New Hampshire \\ Dr. Kalyani Rai \\ University of Wisconsin, Milwaukee \\ Dr. Cathy J. Schlund-Vials \\ University of Connecticut, Storrs \\ Dr. Nancy J. Smith-Hefner \\ Boston University \\ Dr. Yer J. Thao \\ Portland State University \\ Dr. Monica M. Trieu \\ Purdue University \\ Dr. Silvy Un \\ Saint Paul Public Schools \\ Dr. Terrence G. Wiley \\ Center for Applied Linguistics
}

\author{
Dr. Sothy Eng \\ Lehigh University
}

Dr. Zha Blong Xiong

University of Minnesota

Dr. Peter Tan Keo

New York University

Dr. Kevin K. Kumashiro

University of San Francisco

Dr. Ravy Lao

California State University, Los

Dr. Stacey Lee

University of Wisconsin, Madison

Dr. Sue Needham

California State University, Dominguez Hills

Dr. Max Niedzwiecki

Daylight Consulting Group

Dr. Clara Park

California State University, Northridge

Dr. Giang Pham

University of Massachusetts

Dr. Karen Quintiliani

California State University, Long Beach

Dr. Phala Chea

Lowell Public Schools

Dr. Fay Shin

California State University, Long Beach

Dr. Christine Su

Ohio University

Dr. Alisia Tran

Arizona State University

Dr. Khatharya Um

University of California, Berkeley

Dr. Linda Trinh Vo

University of California, Irvine

Dr. Yang Sao Xiong

University of Wisconsin-Madison

\section{Doctoral Student Editorial Review Board}

\author{
Anna H. Yang \\ University of Georgia
}

\author{
Dung Minh Mao \\ University of Minnesota
}




\author{
Annie BichLoan Duong \\ San Joaquin County Office of Education \\ Hoa Nha Nguyen \\ Boston College \\ Malaphone Phommasa \\ Marshall University \\ Molly Wiebie \\ The University of Texas at Austin
}

\author{
Thien-Huong Ninh \\ University of Southern California \\ Krissyvan Truong \\ Claremont Graduate University \\ Soua Xiong \\ San Diego State University \& Claremont \\ Graduate University
}

